\title{
Defective Antigen Presentation and Novel Structural Properties of DR1 from an HLA Haplotype Associated with 21-Hydroxylase Deficiency
}

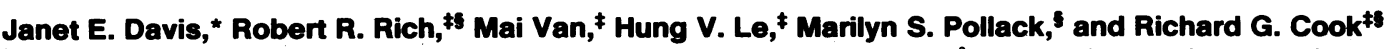 \\ ${ }^{\ddagger}$ The Howard Hughes Medical Institute Laboratory and the Department of ${ }^{\S}$ Microbiology and Immunology, Baylor College of \\ Medicine, Houston, Texas 77030; and the *Graduate School of Biomedical Sciences, University of Texas, Houston, Texas 77225
}

\begin{abstract}
We have segregated DR1 ${ }^{+}$individuals into two categories according to whether or not their class $\mathrm{II}^{+}$cells stimulated $\mathrm{T}$ lymphocyte clones specific for or restricted to DR1. In a majority of cases (87\%), failure to stimulate was a property of cells having the B14;DR1 haplotype and/or nonclassical 21-hydroxylase deficiency. Absence of clonal proliferation could not be explained by release of an intercellular suppressor factor or by stimulator cell absorption of interleukin 2. Homozygous cells inheriting both stimulatory $\left(\mathrm{DR1}_{n}\right)$ and nonstimulatory (DR1 $1_{x}$ haplotypes did not successfully mediate clonal expansion, implying that a trans acting factor operates intracellularly to modify both DR1 alleles or their products. Other DR alleles did not appear to be affected as evidenced by normal proliferative responses of $T$ lymphocyte clones restricted to DR2 or DR7 and stimulated by DR1, 2 and $D R 1_{x}, 7$ cells, respectively. By two-dimensional gel analysis, we have further identified a 50-kD surface glycoprotein contained in anti-DR immunoprecipitates of $D R 1_{x}$, but not $D R 1_{n}$ or non-DR1 cellular lysates. This $50-\mathrm{kD}$ structure had antigenic and peptide identity to $\mathrm{DR} \alpha$ and $\beta$ chains but was resistant to dissociation under conditions that normally separate DR $\alpha$ and $\beta$ (8 M urea plus 5\% 2-mercaptoethanol); boiling in sodium dodecyl sulfate was required to segregate the component polypeptides of the 50-kD heterodimer. We postulate that a product of a novel combinatorial association between constitutive chains of DR may interfere with or compete for normal $T$ cell receptor recognition of DR1 as both an alloantigen and a restricting element. We further propose that gene abnormalities within the class III region of a haplotype associated with nonclassical 21-hydroxylase deficiency may extend into the DR subregion of the major histocompatibility complex with consequent aberrations in DR1 presentation.
\end{abstract}

\section{Introduction}

Class II genes of the human major histocompatibility complex (MHC) encode a set of protein products responsible for mediating activation of $\mathrm{T}$ helper/inducer cells of the immune system. The class II heterodimer expressed by cells in which these genes are active is constructed from distinct $\alpha$ (32-34 $\mathrm{kD})$ and $\beta(26-29 \mathrm{kD})$ chains noncovalently complexed to-

Address reprint requests to Dr. R. G. Cook, M929 DeBakey Center, One Baylor Plaza, Houston, TX 77030.

Received for publication 23 January 1987 and in revised form 1 June 1987.

J. Clin. Invest.

(c) The American Society for Clinical Investigation, Inc. 0021-9738/87/10/0998/11 $\$ 2.00$

Volume 80, October 1987, 998-1008 gether. $\mathrm{T}$ cell receptors of $\mathrm{CD} 4^{+}$cells recognize processed antigen coupled with autologous class II complexes displayed at the surface of an antigen-presenting cell (APC) ${ }^{1}$ (reviewed in reference 1). The relevant class II complexes involved in this process are derived from genes of the DP, DQ, and DR subregions, as has been shown with appropriate monoclonal antibody (mAb) blocking studies (2) and with the identification of $T$ cell clones specific for epitopes of these products (2-5). However, structural details pertaining to the molecular affiliations and the sequence of interactions between $T$ cell receptor, antigen, and the two constituent chains of class II structures continue to be a provocative issue.

Severe deficiency of 21-hydroxylase $(21-\mathrm{OH})$ causes a recessive inborn error of metabolism known as congenital adrenal hyperplasia. A lack of sufficient $21-0 H$ enzyme activity interrupts normal adrenal steroidogenesis such that the immediate precursor in the pathway, 17-hydroxyprogesterone, is shunted into excessive production of androgens with subsequent symptoms of virilization. Multiple variants of the disease have been described (reviewed in reference 6), which range in severity from the classical "salt wasting" and "simple virilizing" forms present at birth to the nonclassical "cryptic" and "late onset" variants where clinical symptoms fail to become evident or are not apparent until puberty. Different forms of the disease are frequently inherited in genetic linkage disequilibrium with different extended HLA haplotypes $(7,8)$. In the case of nonclassical 21-OH deficiency, this haplotype includes HLA-DR1 and B14 (8). Two genes for 21-OH, one active and one nonfunctional, have been mapped alternating with the complement $\mathrm{C} 4 \mathrm{~A}$ and $\mathrm{C} 4 \mathrm{~B}$ genes within the class III region of the human $\mathrm{MHC}(9,10)$. Although there is extensive evidence documenting a deletion of the active $21-\mathrm{OHB}$ gene in some cases of classical 21-OH deficiency (11), other reports have referred to a duplication of both the C4B gene (12) and one 21-OH gene (11) in some cases of nonclassical 21-OH deficiency. It remains unclear to what extent DNA rearrangements have functionally altered particular genes associated with the disease and whether those modifications are confined to the class III region of the affected haplotypes.

Despite the location of $21-\mathrm{OH}$ genes within the human MHC adjacent and telomeric to DR subregion genes, no consistent associations with immunological abnormalities, in particular antigen presentation by class II structures, have been described in 21-OH-deficient patients or related obligate carriers. In this report, we demonstrate failure of certain $\mathrm{DR}^{+}$

1. Abbreviations used in this paper: APC, antigen-presenting cell; ATCC, American Type Culture Collection; 2-D, two-dimensional; EBV, Epstein-Barr virus; IEF, isoelectric focusing; $\mathrm{mAb}$, monoclonal antibody; PBMC, peripheral blood mononuclear cells; SRBC, sheep red blood cell; $\left[{ }^{3} \mathrm{H}\right] \mathrm{TdR}$, tritiated thymidine; TLC, T lymphocyte clone; TNP, trinitrophenyl. 
cells to mediate activation and proliferation of some DR1-restricted or specific $\mathrm{T}$ lymphocyte clones. This does not appear to reflect a "split" of the DR1 alloantigen and seems to be inherited in a dominant fashion, usually in linkage disequilibrium with HLA-B 14 and nonclassical $21-\mathrm{OH}$ deficiency. Only some epitopes of the DR 1 antigenic complex are involved with the defective trait, and successful presentation of other DR allelic products is not obstructed. We further show that deviant antigen presentation is positively correlated with the presence of a novel $50-\mathrm{kD}$ surface structure having DR peptide and antigenic homology.

\section{Methods}

Human T lymphocyte clones (TLC). Methods for the derivation, cloning, and screening of $\mathrm{T}$ cells used in this study have been detailed elsewhere (13). Clone GM-1C1 was cloned from a bulk population of responder GMc cells (A11,24; Bw58,w60; Cw3,w5; DR1,7; DQwl,w2; DRw53; DPw2,w4) that had been sequentially stimulated with trinitrophenyl (TNP)-modified peripheral blood mononuclear cells (PBMC) of the same donor. Clone RD-2A4 originated from a primary mixed lymphocyte response between PBMC of responder RD (A1,w30; B8,49; DR3,w6; DQw1,w2; DPw2,w4) and irradiated stimulator PBMC from GMc. Clonal expansion was carried out with antigenic stimulation every $7 \mathrm{~d}$ in Linbro 24-well plates (Flow Laboratories, Inc., McLean, VA) by using $0.5 \times 10^{6}$ cloned responder cells mixed with $1.0 \times 10^{6}$ irradiated $\left(3,000 \mathrm{rad}\right.$ from a ${ }^{60} \mathrm{Co}$ source) PBMC in a total volume of $1.0 \mathrm{ml}$ RPMI 1640 medium supplemented with 2 $\mathrm{mM}$ L-glutamine, $50 \mu \mathrm{g} / \mathrm{ml}$ gentamicin sulfate (Gibco, Grand Island, NY), 24 mM sodium bicarbonate (Mallinckrodt, Inc., St. Louis, MO), 25 mM HEPES (Sigma Chemical Co., St. Louis, MO), 10\% human serum from defibrinated plasma, and 5-10\% interleukin 2 (IL-2)-containing medium. Where the responding clone was specific for TNP, stimulator cells were conjugated with trinitrobenzene sulfonic acid (ICN Nutritional Biochemicals, Cleveland, $\mathrm{OH}$ ) by methods previously described (14). Cells were passed over Isolymph (Teva, Ltd., Jerusalem, Israel) density gradients to remove cellular debris and residual stimulator cells before cryopreservation in $90 \%$ fetal calf serum (FCS; Gibco) with 10\% dimethylsulfoxide (DMSO). After 5 mo of in vitro expansion, both clones were $>98 \%$ positive by flow cytometric analysis for $\mathrm{CD} 3, \mathrm{CD} 4, \mathrm{CD} 2$, and $\mathrm{DR}$ surface antigens and $<3 \%$ positive for the CD8 marker.

$I L-2$. IL-2-containing medium was prepared from spleens of trauma patients, as previously described (13), or from buffy coats (Gulf Coast Regional Blood Center, Houston, TX) according to existing protocols $(15,16)$. IL-2-containing supernatants were harvested by centrifugation at $800 \mathrm{~g}$, stored at $-70^{\circ} \mathrm{C}$, and passed through $0.45-\mu \mathrm{m}$ filters (Becton Dickinson \& Co., Oxnard, CA) before use. Quantitation of IL- 2 in conditioned medium was assessed by the ability of supernatants to support growth of HT-2 cells (17) relative to a known IL-2 standard (Jurkat human IL-2; Biological Response Modifiers Program, National Cancer Institute, Frederick, MD). Our preparations of IL-2containing medium generally held 30-60 U IL-2/ml and were used at final concentrations between 5 and $10 \%$.

Leukocyte isolation. Heparinized blood was obtained from consenting donors by venipuncture or leukapheresis. PBMC were fractionated on Isolymph density gradients according to the method of Böyum (18), washed once in Hanks' balanced salt solution (Gibco), resuspended in supplemented RPMI 1640 with $10 \%$ FCS, and depleted of platelets by centrifuging at $200 \mathrm{~g}$ through a solution of RPMI 1640 with $10 \%$ FCS and $28.6 \%$ Isolymph. Pelleted cells were washed twice and used immediately or cryopreserved.

Epstein-Barr virus (EBV)-transformed lines. Difficulties in procuring blood samples in some cases necessitated the production of EBV-transformed B cell lines. PBMC were resuspended to $1 \times 10^{6}$ cells/ml in supplemented RPMI 1640 with $10 \%$ FCS, and a dilution of
EBV (B95-8 virus; Showa University Research Institute, St. Petersburg, FL) was added to a final concentration of $6.25 \times 10^{6}$ transforming $\mathrm{U} / \mathrm{ml}$. Cells were plated at $200 \mu \mathrm{l} /$ well of a 96 -well flat-bottom plate (Costar Data Packaging Corp., Cambridge, MA) and were cultured for $3 \mathbf{d}$ after which medium was aspirated and replaced. Individual wells were thereafter pooled and expanded as growth permitted. All TLC and EBV-transformed lines were maintained free of mycoplasma and routinely assayed using the Hoechst dye 33258 (Calbiochem-Behring Corp., La Jolla, CA) method of Chen (19).

HLA typing. Donor leukocytes were typed for HLA-A, B, C, DR, DQ histocompatibility antigens using standard serologic techniques $(20,21)$. Mononuclear cells from venous blood were fractionated on Lymphoprep (Nyegaard Co., Oslo, Norway) density gradients and passed over nylon-wool (Fenwall Laboratories, Berkeley, CA) columns. Nonadherent cells were collected and typed for HLA-A, B, C antigens. Nylon-wool adherent cells were recovered and typed for DR and DQ antigens. DP antigens were typed using standard primed lymphocyte typing procedures (22).

$A C T H$ testing. Individuals consenting to undergo ACTH testing were administered a 0.25 -mg bolus of Cortrosyn intravenously between 8:00 and 9:30 a.m. Blood was drawn just before and at 30 and 60 min after Cortrosyn injection. Levels of 17-hydroxyprogesterone were measured using a radioimmunoassay after chromatography of the plasma extract (23). Plasma cortisol concentrations were also measured to ensure that an effective dose of ACTH had been administered.

Stimulation assays. All assays were carried out in 96-well roundbottom plates (Costar Data Packaging Corp.) using clonal expansion medium in the absence of exogenous IL-2. Stimulator cells were irradiated, 3,000 rad in the case of PBMC and 15,000 rad in the case of EBV-transformed lines. For assay, cloned responder $T$ cells $\left(1 \times 10^{5}\right.$ per well) were mixed with an equal number of stimulator cells, 200 $\mu \mathrm{l} /$ well, and cultured $48 \mathrm{~h}$. Proliferative responses were measured by the addition of $1 \mu \mathrm{Ci} /$ well tritiated thymidine $\left(\left[{ }^{3} \mathrm{H}\right] \mathrm{TdR} ; 20 \mathrm{Ci} / \mathrm{mM}\right.$ sp act; Amersham Corp., Arlington Heights, IL) over the final 20-24 h of incubation. Cultures were harvested onto glass fiber filter mats using a Skatron cell harvesting system (Skatron, Inc., Sterling, VA). Dried filter disks were immersed in liquid scintillation cocktail and counted on a liquid scintillation counter (LS7500; Beckman Instruments, Inc., Irvine, CA). Data are expressed as mean counts per minute of incorporated $\left[{ }^{3} \mathrm{H}\right] \mathrm{TdR}$ from triplicate cultures with the SEM.

Lymphocyte fractionation and activation. Enriched fractions of resting T and B cells were isolated by twice sheep red blood cell (SRBC; Bethyl Laboratories, Montgomery, TX) rosetting as has been described (24). Activated T cell blasts were recovered on day 4 from concanavalin A (Con A; $10 \mu \mathrm{g} / \mathrm{ml}$; Pharmacia Fine Chemicals AB, Uppsala, Sweden)-treated cultures. Activated B cell blasts were recovered from day 7 lipopolysaccharide (LPS; $50 \mu \mathrm{g} / \mathrm{ml}$; Difco Laboratories Inc., Detroit, MI)-dextran sulfate ( $20 \mu \mathrm{g} / \mathrm{ml}$; Sigma Chemical Co.)-treated cultures. Blasts were passed over an Isolymph density gradient to remove dead cells and debris before subsequent manipulation.

Cellular radiolabeling and immunoprecipitation. Lactoperoxidasecatalyzed cell surface iodination, ${ }^{35} \mathrm{~S}$-methionine metabolic labeling, preparation of detergent lysates, lysate preclearing, and immunoprecipitations were all carried out as has been described (25). 10-20 × 106 viable cells were washed twice in phosphate-buffered saline (PBS; Gibco) and resuspended in $100 \mu$ l of the same, followed by additions over $15 \mathrm{~min}$ at room temperature of 1-2 mCi sodium ${ }^{125} \mathrm{I}(10-20 \mu \mathrm{l}$; Amersham Corp.) in combination with $150 \mu$ l lactoperoxidase (1 $\mathrm{mg} / \mathrm{ml}$; Sigma Chemical Co.) and $180 \mu \mathrm{l} \mathrm{H}_{2} \mathrm{O}_{2}$ (0.03\%). Alternatively, $10-20 \times 10^{6}$ cells were resuspended at $2 \times 10^{6} / \mathrm{ml}$ in methionine-free RPMI 1640 (Inland Laboratories, Austin, TX) with 15\% dialyzed FCS and $0.5-1.0 \mathrm{mCi}^{35} \mathrm{~S}$-methionine (Amersham Corp.) and were incubated $12-18 \mathrm{~h}$ at $37^{\circ} \mathrm{C}$. Radiolabeled cells were washed 2-3 times in PBS before lysing in 0.5\% NP-40 (Gallard-Schlesinger Chemical Mfg. Corp., Carle Place, NY); in PBS supplemented with the protease inhibitors $\mathrm{ZnCl}_{2}(50 \mu \mathrm{M})$; in aprotinin $(33 \mu \mathrm{g} / \mathrm{ml}$; Boehringer Mannheim GmbH, Mannheim, FRG); and in phenylmethylsulfonylfluoride (1 $\mathrm{mM}$; Boehringer Mannheim GmbH). Preclearing mAbs included 
OKT3 or OKT11 (Ortho Pharmaceutical, Raritan, NJ) or P3X63Ag8 myeloma (P3X; American Type Culture Collection (ATCC), Rockville, MD) culture supernatant. Anti-class II immunoprecipitations were conducted with excess L243 (ATCC), L227 (ATCC) (26), DakoHLA-DR (Dakopatts, Copenhagen, Denmark), 2D6 (27), Genox 3.53 (ATCC) (28), Leu 10 (ATCC) (29), B7/21 (gift from Dr. Nancy Reinsmoen, University of Minnesota, Minneapolis, MN) (30), or L203 (gift from Dr. Ronald Levy, Stanford University Medical Center, Stanford, CA) (26) mAb culture supernatants. Immune complexes were isolated with Staphylococcus aureus, Cowan strain I (Bethesda Research Laboratories, Gaithersburg, MD) and were eluted in the presence of 5\% 2-mercaptoethanol unless otherwise indicated.

Two-dimensional (2-D) polyacrylamide gel electrophoresis (PAGE). Immunoprecipitated molecules were analyzed by 2-D PAGE according to published protocols (25) using a $3.5-9 \mathrm{pH}$ gradient isoelectric-focusing (IEF) gel in the first dimension and a $10 \%$ polyacrylamide slab gel in the second dimension. Gels were fixed, unless otherwise stated, dried, and autoradiographed at $-70^{\circ} \mathrm{C}$ using Kodak XAR-5 film (Eastman Kodak Co., Rochester, NY) with intensifying screens.

2-D Western blotting. 2-D slab gels containing unlabeled, immunoprecipitated cellular proteins were electroblotted to nitrocellulose paper (Schleicher \& Schuell Inc., Keene, NH) by methods previously described (31). Nonspecific binding sites were blocked by incubation in $0.05 \mathrm{M}$ Tris-buffered saline with $5 \%$ nonfat dry milk, followed by an overnight exposure to mAb culture medium, and exposed an additional $6 \mathrm{~h}$ to ${ }^{125} \mathrm{I}$-sheep anti-mouse Ig (Amersham Corp.). Washed and dried blots were autoradiographed as above.

Cleveland peptide mapping. Peptide mapping was performed essentially as has been described (32). 2-D gels were dried and autoradiographed without prior fixation, and the molecules of interest were excised and eluted overnight at $37^{\circ} \mathrm{C}$ into $0.125 \mathrm{M}$ Tris buffer, $\mathrm{pH} 6.8$, containing $0.1 \%$ sodium dodecyl sulfate (SDS) and $20 \%$ glycerol. Aliquots of eluted material, boiled or not boiled, were loaded into lanes of a $15 \%$ acrylamide gel having a $7-\mathrm{cm} 4 \%$ acrylamide-stacking gel and were overlayered with $50 \mu \mathrm{l}$ of diluted enzyme in $0.125 \mathrm{M}$ Tris buffer, pH 6.8, with $10 \%$ glycerol, $0.1 \%$ SDS, and bromophenol blue. Digestive enzymes included Staphylococcus aureus V8 protease (1 or 10 $\mu \mathrm{g} /$ well; Miles Laboratories, Inc., Naperville, IL), chymotrypsin ( $2 \mu \mathrm{g} /$ well; Miles Laboratories, Inc.), and papain ( 0.9 pg/well; Sigma Chemical Co.).

\section{Results}

Failure of some $\mathrm{DRI^{+ }}$ cells to stimulate DRI-restricted and -specific TLC. Previous screening and mAb-blocking studies performed in this laboratory have established that clone GM-1C1 was specific for TNP in the context of DR1 (27), whereas clone RD-2A4 was alloreactive and specific for DR1. However, extensive panel analysis of both clones revealed that stimulator cells from a significant number of $\mathrm{DR}^{+}$individuals were not able to mediate clonal expansion as measured in a standard proliferation assay. Representative data illustrating this finding are shown in Table I where PBMC from donors GLG, ReG, and OrB were not able to promote $\left[{ }^{3} \mathrm{H}\right] \mathrm{TdR}$ incorporation by either clone despite the serologically defined presence of DR1 on the surface of these cells. In all instances, equivalent clonal proliferation results were observed whether $\mathrm{DR} 1^{+}$allogeneic stimulators were prepared from PBMC or EBV-transformed lines. Ability or inability to stimulate was always a property equally applicable to both the alloreactive and TNP-specific clones; no antigen-presenting cell ever stimulated one clone but not the other.

We have used the following nomenclature to define this functional dichotomy between some $\mathrm{DR}^{+}{ }^{+}$stimulators. Cells
Table I. Proliferative Responses of DRI-Specific or-Restricted TLC

\begin{tabular}{llcc}
\hline & & \multicolumn{2}{c}{$\left.{ }^{3}{ }^{3}\right]_{\text {PBMymidine incorporation }}^{*}$} \\
\cline { 3 - 4 } stimulator & HLA genotype & Clone RD-2A4* & Clone GM-1C1 \\
\hline GMc & DR1,7 & $44,883 \pm 941$ & $25,940 \pm 5,025$ \\
DaL & DR1,7 & $45,740 \pm 699$ & $32,443 \pm 1,539$ \\
ReG & DR1,4 B14 cis & $1,733 \pm 418$ & $1,790 \pm 540$ \\
OrB & DR1,2 B14 cis & $2,089 \pm 821$ & $1,542 \pm 220$ \\
GLG & DR1,3 B14 trans & $2,037 \pm 712$ & $1,423 \pm 375$ \\
AmCS & DR1,7 B14 trans & $39,147 \pm 687$ & $25,253 \pm 1,516$ \\
RaD & DR3,w6 & $2,030 \pm 178$ & $2,257 \pm 731$ \\
\hline & & & \\
\hline
\end{tabular}

* Results are expressed as mean counts per minute $\left[{ }^{3} \mathrm{H}\right]$ thymidine incorporation for three replicate cultures \pm SEM at the peak of the proliferative response at $48 \mathrm{~h}$. Proliferative responses of PBMC stimulators alone or clone alone were consistently $<2,000 \mathrm{cpm}$. ¥ Clone RD-2A4, an alloreactive clone specific for DR1.

${ }^{8}$ Clone GM-1C1, a TNP-specific clone restricted to DR1. Proliferative responses are shown for hapten-modified cells. Responses of unmodified cells with clone averaged $<2,000 \mathrm{cpm}$.

that were proficient stimulators of either clonal response carried the phenotypic designation $\mathrm{DR} 1_{n}$, whereas cells that were ineffective stimulators were designated $D R 1_{x}$.

Table II summarizes the proliferative responses of clones GM-1C1 and RD-2A4 to all stimulator cells of our panel. Non-DR 1 stimulator cells were not able to induce clonal activation that was consistent with the restriction specificity of these clones. Dissecting the $\mathrm{DR} 1^{+}$portion of our panel, it became apparent that most cells of the $D R 1_{x}$ phenotype also carried B14 on the same haplotype with DR1 ( 24 of 33 cases). In contrast, most cells of the $\mathrm{DR} 1_{\mathrm{n}}$ phenotype failed to type for B14 on either haplotype or carried B14 on the haplotype op-

Table II. Summary of Proliferative Responses by Clones $G M-1 C 1$ and $R D-2 A 4$

\begin{tabular}{|c|c|c|c|}
\hline \multirow[b]{2}{*}{ Genotype } & \multicolumn{2}{|c|}{ No. of individuals that serve as } & \multirow[b]{2}{*}{ Total } \\
\hline & $\begin{array}{l}\text { Stimulator } \\
\left(\mathrm{DR} 1_{\mathrm{n}}\right)\end{array}$ & $\begin{array}{l}\text { Nonstimulator } \\
\left(\mathrm{DR} 1_{\mathbf{x}}\right)\end{array}$ & \\
\hline Non-DR 1 & $0(0.0 \%)$ & $25(100.0 \%)$ & 25 \\
\hline \multicolumn{4}{|l|}{ DR1 } \\
\hline DR1, not B14 & $12(81.5 \%)$ & $5(18.5 \%)$ & 17 \\
\hline $\mathrm{DR} 1, \mathrm{~B} 14$ cis & $4(14.3 \%)$ & $24(85.7 \%)$ & 28 \\
\hline DR1, B14 trans & $3(42.8 \%)$ & $4(57.1 \%)$ & 7 \\
\hline \multirow[t]{2}{*}{ Total } & 19 & 33 & 52 \\
\hline & \multicolumn{2}{|c|}{ No. of unrelated haplotypes that serve as } & \\
\hline Genotype & $\begin{array}{l}\text { Stimulator } \\
\left(\mathrm{DR} 1_{\mathrm{n}}\right)\end{array}$ & $\begin{array}{l}\text { Nonstimulator } \\
\left(\mathrm{DR} 1_{\mathbf{x}}\right)\end{array}$ & Total \\
\hline Non-DR1 & $0(0.0 \%)$ & $25(100.0 \%)$ & 25 \\
\hline \multicolumn{4}{|l|}{ DR1 } \\
\hline DR1, not B14 & $21(84.0 \%)$ & $4(16.0 \%)$ & 25 \\
\hline $\mathrm{DR} 1, \mathrm{~B} 14$ cis & $2(11.8 \%)$ & $15(88.2 \%)$ & 17 \\
\hline DR1, B14 trans & $3(60.0 \%)$ & $2(40.0 \%)$ & 5 \\
\hline Total & 26 & 21 & 47 \\
\hline
\end{tabular}


posite that of DR 1 ( 15 of 19 cases). Thus, the $\mathrm{B} 14^{+} ; \mathrm{DR} 1^{+}$cis haplotype had a positive correlation with the $\mathrm{DR} \mathrm{l}_{\mathrm{x}}$ phenotype $(P<0.001)$, whereas the $\mathrm{B} 14^{-} ; \mathrm{DR} 1^{+}$haplotype correlated with the DR $1_{n}$ phenotype $(P<0.001)$. This conclusion was also true when haplotypes from multiple related individuals were excluded in the final statistical analysis (bottom, Table II). Exceptions to these generalizations are interesting and may reflect recombination events in the ancestry of these cells such that B14 has segregated away from or recombined with the DR 1-bearing haplotype.

Apparent linkage of the DR $1_{x}$ phenotype with nonclassical 21-OH deficiency. As stated earlier, the B14;DR1 haplotype and its associated complotype (C4A2; C2C; BFS; C4B1,2) are commonly inherited in conjunction with nonclassical $21-\mathrm{OH}$ deficiency $(8,12)$. Previously reported results indicate that the B14;DR1 supratype can reliably predict the clinical status of individuals not formerly known to be 21-OH deficient carriers (33). Of 21 individuals from our panel whose cells manifested the DR $1_{x}$ phenotype and who consented to undergo ACTH testing, 19 were carriers or homozygous patients with nonclassical 21-OH deficiency. 12 of these 19 were known to carry B14 on the same haplotype with DR 1; of the remainder, genotyping was not possible in three cases and B14 was trans to DR 1 in three cases (related siblings) or absent from both haplotypes in one case. This high frequency of association (90.5\%) between the incompetent DR1 stimulator status and 21-OH deficiency would suggest that both characteristic traits are inherited in strong linkage disequilibrium. However, in one categorical DR $1_{x}$ individual 21-OH deficiency was apparent without the B14 marker; three other individuals with the DR $1_{x}$ phenotype did not inherit the B14 allele and were not 21-OH deficient. This would imply that the distance between the 21OHB gene and the DR $1_{x}$ gene influencing normal expression of DR1 or between $B 14$ and the DR $1_{x}$ gene is not sufficiently small to prohibit recombination.

Familial segregation of the $D R I_{x}$ phenotype. Both the $D R 1_{x}$ and the $D R 1_{n}$ phenotypic traits appeared to follow normal Mendelian rules of inheritance as evaluated in stimulation assays from family studies (Table III). Effective stimulator status always segregated with the DR $1_{n}$ haplotype (family C), whereas ineffective stimulator status segregated with the B14;DR $1_{\mathrm{x}}$ cis haplotype (family W). It should be noted that individual LiW of family $\mathrm{W}$ is a homozygous DR1 example inheriting the $\mathrm{B} 14 ; \mathrm{DR} 1_{\mathrm{x}}$ cis haplotype of her mother and the $D R 1_{n}$ haplotype of her father. The resulting $D R 1_{x}$ phenotype of this individual's APC suggests that the DR $1_{x}$ trait is expressed in a dominant fashion. The absence of any stimulatory capacity mediated by these heterozygous $D R 1_{x}, D R 1_{n}$ cells further suggests that the phenomenon is not attributable to a serologically undefined split of DR1. Similar results were obtained in another pedigree where cells from the mother expressed the $\mathrm{B} 14 ; \mathrm{DR} 1_{\mathrm{x}}$ cis phenotype, cells from the father carried the DR $1_{n}$ phenotype, yet APC from their DR $1_{x}, 1_{n}$ daughter did not mediate clonal expansion (data not shown).

$D R 1_{x}$ cells do not secrete a suppressor factor. To determine whether failure to promote adequate clonal proliferation was due to secretion of a nonspecific soluble or cellular-bound suppressor factor, irradiated DR $1_{\mathrm{x}}$ stimulator cells from EBVtransformed B cell lines were mixed with a similar irradiated fraction of DR $1_{n}$ stimulators (Table IV). No obvious suppression was apparent; graded decreases in the overall number of effective DR $1_{n}$ stimulator cells per well correlated with a concomitant decrease in $\left[{ }^{3} \mathrm{H}\right] \mathrm{TdR}$ incorporation. This suggests that failure to induce clonal expansion resulted from improper or altered presentation of the DR1 antigen and not from a suppressor factor that depressed clonal activation.

Table III. The DR $1_{x}$ Phenotype Segregates with the B14;DRI Haplotype

\begin{tabular}{|c|c|c|c|c|c|}
\hline \multirow[b]{2}{*}{ Family } & \multirow[b]{2}{*}{ PBMC stimulator } & \multirow[b]{2}{*}{ Relation } & \multirow[b]{2}{*}{ Phenotype } & \multicolumn{2}{|c|}{$\left[{ }^{3} \mathrm{H}\right]$ Thymidine incorporation ${ }^{*}$} \\
\hline & & & & Clone RD-2A4 $4^{\ddagger}$ & Clone GM- $1 \mathrm{Cl}^{3}$ \\
\hline \multirow[t]{4}{*}{ G } & ReG & Daughter & $\mathrm{DR} 1_{\mathrm{x}}, 4 \mathrm{~B} 14 \mathrm{cis}$ & $3,245 \pm 711$ & $783 \pm 31$ \\
\hline & $\mathrm{BrH}$ & Son & DR2,4 & $2,770 \pm 653$ & $592 \pm 30$ \\
\hline & OrB & Mother & $\mathrm{DR} 1_{\mathrm{x}}, 2 \mathrm{~B} 14$ cis & $3,000 \pm 723$ & $582 \pm 33$ \\
\hline & JoW & Father & DR4,5 & $2,851 \pm 122$ & $559 \pm 36$ \\
\hline \multirow[t]{3}{*}{ W } & RoW & Mother & $\mathrm{DR} 1_{\mathrm{x}}, 2 \mathrm{~B} 14$ cis & $2,363 \pm 436$ & $880 \pm 98$ \\
\hline & $\mathrm{MiW}$ & Father & $D R 1_{n}, w 8$ & $43,367 \pm 1,946$ & $21,733 \pm 121$ \\
\hline & LiW & Daughter & $\mathrm{DR} 1_{\mathrm{x}} / 1_{\mathrm{n}} \mathrm{B} 14$ cis & $3,185 \pm 548$ & $2,479 \pm 145$ \\
\hline \multirow[t]{2}{*}{$\mathbf{M}$} & GMc & Brother & $\mathrm{DR} 1_{\mathrm{n}}, 7$ & $39,891 \pm 1,275$ & $26,536 \pm 495$ \\
\hline & RMc & Brother & $\mathrm{DR} 2,7$ & $1,127 \pm 242$ & $770 \pm 145$ \\
\hline \multirow[t]{2}{*}{ C } & AmCS & Father & $\mathrm{DR} 1_{n}, 7 \mathrm{~B} 14$ trans & $38,783 \pm 1,404$ & $25,583 \pm 755$ \\
\hline & ToC & Son & DR4,7 & $1,978 \pm 112$ & $6,233 \pm 703$ \\
\hline \multirow[t]{3}{*}{$\mathbf{P}$} & ViW & Daughter & $\mathrm{DR} 1_{\mathrm{x}}, 5 \mathrm{~B} 14$ cis & $3,150 \pm 429$ & $970 \pm 140$ \\
\hline & ELP & Daughter & $\mathrm{DR} 1_{\mathrm{x}}, 2 \mathrm{~B} 14$ cis & $923 \pm 54$ & $993 \pm 58$ \\
\hline & MiG & Mother & $\mathrm{DR} 2,5$ & $2,543 \pm 67$ & $917 \pm 228$ \\
\hline
\end{tabular}

\footnotetext{
* Results are expressed as mean counts per minute $\left[{ }^{3} \mathrm{H}\right]$ thymidine incorporation for three replicate cultures \pm SEM at the peak of the proliferative response at $48 \mathrm{~h}$. Proliferative responses of PBMC stimulators alone or clone alone were consistently $<2,000 \mathrm{cpm}$. ${ }^{\ddagger} \mathrm{Clone}$ RD-2A4, an alloreactive clone specific for DR1. ${ }^{8}$ Clone GM-1C1; a TNP-specific clone restricted to DR1. Proliferative responses are shown for modified stimulator cells. Responses of unmodified stimulator cells with clone averaged $<2,000 \mathrm{cpm}$.
} 
Table IV. DR $1_{x}$ Stimulator Cells Do Not Secrete a Suppressor Factor

\begin{tabular}{|c|c|c|}
\hline \multirow[b]{2}{*}{ EBV stimulator (phenotype) } & \multirow[b]{2}{*}{ No. cells $\times 10^{5} /$ well } & \multirow{2}{*}{$\frac{\begin{array}{l}{\left[{ }^{3} \mathrm{H}\right] \mathrm{TdR}} \\
\text { incorporation }\end{array}}{\text { Clone RD-2A4 }}$} \\
\hline & & \\
\hline \multirow[t]{4}{*}{$\operatorname{SaR}\left(D R 1_{n}\right)$} & 1.0 & $35,686 \pm 79$ \\
\hline & 0.75 & $34,811 \pm 2,083$ \\
\hline & 0.5 & $35,199 \pm 1,834$ \\
\hline & 0.25 & $28,908 \pm 1,863$ \\
\hline \multirow[t]{4}{*}{$\mathrm{NeP}\left(\mathrm{DR} 1_{\mathbf{x}}\right)$} & 1.0 & $2,459 \pm 197$ \\
\hline & 0.75 & $2,088 \pm 22$ \\
\hline & 0.50 & $1,556 \pm 179$ \\
\hline & 0.25 & $1,171 \pm 275$ \\
\hline \multirow[t]{4}{*}{ BLP (non-DR1) } & 1.0 & $2,251 \pm 208$ \\
\hline & 0.75 & $1,767 \pm 186$ \\
\hline & 0.5 & $1,677 \pm 405$ \\
\hline & 0.25 & $900 \pm 40$ \\
\hline \multirow[t]{3}{*}{$\mathrm{SaR}+\mathrm{NeP}$} & $(0.75+0.25)$ & $32,509 \pm 2,047$ \\
\hline & $(0.5+0.5)$ & $33,787 \pm 4,346$ \\
\hline & $(0.25+0.75)$ & $26,859 \pm 865$ \\
\hline \multirow[t]{3}{*}{ SaR + BLP } & $(0.75+0.25)$ & $36,857 \pm 3,701$ \\
\hline & $(0.5+0.5)$ & $33,962 \pm 999$ \\
\hline & $(0.25+0.75)$ & $31,440 \pm 1,659$ \\
\hline
\end{tabular}

* Results are expressed as mean counts per minute $\left[{ }^{3} \mathrm{H}\right]$ thymidine incorporation for three replicate cultures \pm SEM at the peak of the proliferative response at $48 \mathrm{~h}$. Proliferative responses of EBV stimulators alone or clone alone were consistently $<4,000 \mathrm{cpm}$.

$\ddagger$ Clone RD-2A4, an alloreactive clone specific for DR1.
$D R I_{x}$ stimulators do not absorb $I L-2$. To ensure that APC of the DR $1_{x}$ phenotype were not preferentially absorbing IL-2 produced by $T$ cell clones in assay and thus preventing clonal utilization of lymphokines essential for cell cycle progression, EBV-transformed lines of the $D R 1_{x}$ and $D R 1_{n}$ phenotypes were stained with anti-Tac mAb (34) (gift from Dr. Thomas Waldmann, National Cancer Institute, National Institutes of Health, Bethesda, MD) to quantitate expression of IL-2 receptors. No IL-2 receptor was detectable by indirect fluorescence on EBV lines from either the $\mathrm{DR} 1_{n}$ or $\mathrm{DR} 1_{x}$ categories; fluorescence profiles were consistently equivalent to or below background staining with anti-CD3 (data not shown). Furthermore, crude supernatants of IL-2-containing medium added to assay at final exogenous concentrations of 10 or $50 \%$ failed to reverse the inability of DR $1_{x}$ EBV lines to stimulate clonal proliferation (data not shown). Thus, it is unlikely that the apparent ineffectiveness of $\mathrm{DR} 1_{x}$ stimulator cells reflected their competitive absorption of IL-2.

$D R 1_{x}$ cells can present other epitopes of $D R 1$ to other $D R 1$ restricted clones. We questioned whether the inability of some $\mathrm{DR}^{+}$cells to serve as efficient stimulators reflected a modification of all potential antigenic determinants of the DR1 complex. To explore this issue, we generated additional clones specific for or restricted to DR1. Clone GM-3G4 was derived from a mixed lymphocyte response using donor GMc as the responding cell type and TNP-modified GMc PBMC as the stimulator cell type. Screening of this clone revealed that all $\mathrm{DR} 1^{+}$cells serve as competent stimulators, including cells with the $D R 1_{x}$ phenotype that are incompetent stimulators of clones GM-1C1 and RD-2A4 (Table V). Consequently, although at least one determinant of the DR1 complex has been deleted or altered, other determinants are unaffected and are capable of being recognized by their corresponding $\mathrm{T}$ cell receptors on other clones.

Table V. DR $1_{x}$ Cells Can Present Other Epitopes of DRI and Other DR Alleles

\begin{tabular}{|c|c|c|c|c|c|}
\hline \multirow[b]{2}{*}{ EBV stimulator } & \multirow[b]{2}{*}{ HLA-DR phenotype } & \multirow[b]{2}{*}{ Clone $1 \mathrm{C}^{\ddagger}$} & \multicolumn{3}{|c|}{$\left.{ }^{3} \mathrm{H}\right]$ Thymidine incorporation ${ }^{*}$} \\
\hline & & & Clone SB-3D5 5 & Clone GM-3G4" & Clone RD-2A4' \\
\hline SaR & $\mathrm{DR} 1_{\mathrm{n}}, 2$ & $57,331 \pm 4,012$ & ND & ND & $23,488 \pm 875$ \\
\hline GMc & $\mathrm{DR} 1_{n}, 7$ & $2,347 \pm 200$ & $14,345 \pm 2,055$ & $24,094 \pm 458$ & $14,574 \pm 411$ \\
\hline $\mathrm{NaD}$ & $D R 1_{x}, 7$ & $1,679 \pm 54$ & $8,787 \pm 340$ & ND & $1,586 \pm 18$ \\
\hline DeM & $\mathrm{DR} 1_{x}, 7$ & $1,757 \pm 90$ & $18,746 \pm 1,486$ & ND & $2,151 \pm 94$ \\
\hline $\mathrm{PaV}$ & $\mathrm{DR} 1_{x}, 7$ & $1,422 \pm 105$ & $10,276 \pm 704$ & ND & $23,299 \pm 2,033$ \\
\hline OrB & $\mathrm{DR} 1_{\mathrm{x}}, 2$ & $59,294 \pm 3,094$ & $1,548 \pm 257$ & ND & ND \\
\hline $\mathbf{R b R}$ & $\mathrm{DR} 1_{x}, 2$ & $57,243 \pm 1,836$ & $2,071 \pm 130$ & ND & $1,600 \pm 624$ \\
\hline $\mathrm{NeP}$ & $D R 1_{x}, 2$ & $59,082 \pm 5,730$ & ND & ND & $4,097 \pm 399$ \\
\hline JoR & $\mathrm{DR} 1_{x}, 7$ & $958 \pm 39$ & $14,062 \pm 655$ & $47,420 \pm 1,372$ & $1,128 \pm 44$ \\
\hline BLP & DR2,4 & $63,335 \pm 3,339$ & ND & ND & $2,466 \pm 202$ \\
\hline $\mathrm{CeG}$ & $D R 1_{n}, 3$ & ND & ND & $61,507 \pm 2,073$ & ND \\
\hline AmCS & $D R 1_{n}, 7$ & ND & $24,440 \pm 1,717$ & $55,113 \pm 1,004$ & $14,373 \pm 1,485$ \\
\hline ViW & $D R 1_{x}, 5$ & ND & ND & $13,357 \pm 327$ & ND \\
\hline DiR & DRw6,7 & ND & ND & $870 \pm 67$ & ND \\
\hline
\end{tabular}

* Results are expressed as mean counts per minute $\left[{ }^{3} \mathrm{H}\right]$ thymidine incorporation for three replicate cultures \pm SEM at the peak of the proliferative response at $48 \mathrm{~h}$. Proliferative responses of EBV stimulators alone or clone alone were consistently $<4,000 \mathrm{cpm}$. $\$ \mathrm{Clone} 1 \mathrm{C} 7$, an alloreactive clone specific for DR2. \$Clone SB-3D5, an alloreactive clone specific for DR7. "Clone GM-3G4, a TNP-specific clone restricted to DR1. "Clone RD-2A4, an alloreactive clone specific for DR1. 
Heterozygous $D R 1_{x}$ cells effectively present other $D R$ allelic products. $\mathrm{DR} 1_{\mathrm{x}}, 2$ and $\mathrm{DR} 1_{\mathrm{x}}, 7$ cells were tested in proliferative assays with alloreactive DR2- or DR7-specific clones to determine whether heterozygous $D R 1_{x}$ cells could successfully stimulate other class II specific clones or if the DR $1_{x}$ phenotype interferes in a trans fashion with normal presentation of any DR allelic product. Table V demonstrates that DR2 and DR7 complexes were adequately presented on the surface of heterozygous $\mathrm{DR} 1_{x}$ APC in a manner that allowed normal stimulation of their respective clones. Therefore, lack of stimulation of the DR1-specific or -restricted clones represents a defect in presentation of some DR1 antigenic determinants, but not other DR allelic products.

Co-precipitation of a 50-kD glycoprotein with $D R$ from some $D R I^{+}$cells. We attempted to compare the molecular profile of $D \dot{R} 1_{x}$ and $D R 1_{n}$ antigens using standard techniques designed to separate these molecules by charge and molecular weight. When radioiodinated cellular lysates were subjected to immunoprecipitation with anti-DR mAbs followed by IEF in the first dimension and SDS-PAGE in the second dimension, we identified a unique species having a molecular weight of 50 $\mathrm{kD}$ and an isoelectric point (pI) between 5 and 6 that co-pre-

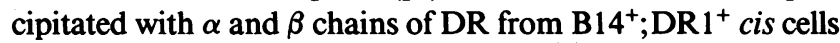
(Fig. $1 \mathrm{~B}$ ), but not from $\mathrm{B} 14^{-}$;DR $1^{+}$cells (Fig. $1 \mathrm{~A}$ ) or $\mathrm{B}^{1} 4^{+} ; \mathrm{DR} 1^{-}$cells (data not shown). The presence of this $50-\mathrm{kD}$ moiety correlated well $(P<0.001)$ with the $\mathrm{DR} 1_{\mathrm{x}}$ phenotype (Table VI). Lysates of cells from 19 of 21 individuals tested who manifested the $\mathrm{DR} 1_{\mathrm{x}}$ phenotype contained the $50-\mathrm{kD}$ species that co-precipitated with anti-DR mAbs. In contrast, only 1 of 18 cellular lysates from individuals exhibiting the $\mathrm{DR} 1_{\mathrm{n}}$ phenotype contained the co-precipitating $50-\mathrm{kD}$ species. Because presence or absence of the 50-kD molecule was con-

L243
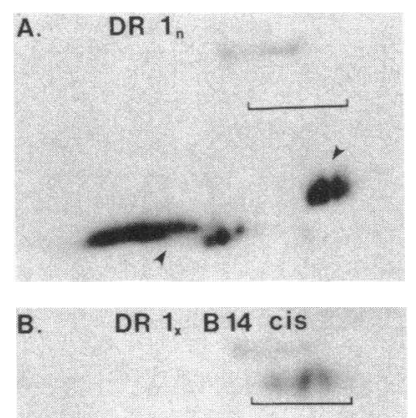

L243
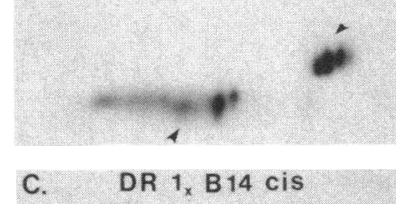

P3X
Figure 1. Comparative 2-D PAGE analysis of anti-DR immunoprecipitates from $D R 1_{x}$ and DR $1_{n}$ PBMC cellular lysates. DR complexes were precipitated with the mAb L243 ( $A$ and $B)$ from a DR $1_{n}$ PBMC lysate (SaR, $A$ : HLA-A3,w23; B7,w35; $\mathrm{C}-,-$; DR 1,2) and a DR $1_{x}$ PBMC lysate (GLG, $B$ and $C$ : HLA-A28,w34; Bw53,14; Cw4,w5; DR1,w8); culture supernatant from the murine myeloma P3X63Ag8 served as the negative control precipitating reagent $(C)$. The portion of each autoradiograph shown represents identical areas of the IEF (pH $\sim 3.5-9.5$, right to left)

and PAGE ( 60-20 kD, top to bottom) dimensions. DR $\beta$ molecules are designated by an up arrowhead and DR $\alpha$ molecules, by a down arrowhead. Brackets mark areas of the gel in which molecules of $50 \mathrm{kD}$, pI 5-6 would be expected to appear.
Table VI. Correlation Between Clonal Stimulation and $50 \mathrm{kD}$ Glycoprotein

\begin{tabular}{llc}
\hline & \multicolumn{2}{l}{ No. positive for $50 \mathrm{kD} / \mathrm{no}$. tested } \\
\cline { 2 - 3 } Genotype & Stimulators $\left(\mathrm{DR} \mathbf{1}_{\mathrm{n}}\right.$ ) & Nonstimulators (DR $\mathbf{1}_{\mathbf{x}}$ ) \\
\hline Non-DR1 & $0 / 0$ & $1 / 10$ \\
DR1 & & \\
DR1, not B14 & $0 / 15$ & $3 / 3$ \\
DR1, B14 cis & $1 / 1$ & $15 / 15$ \\
DR1, B14 trans & $0 / 2$ & $1 / 3$ \\
Total & $1 / 18$ & $19 / 21$ \\
\hline
\end{tabular}

sistent for any given stimulator cell source, was equally perceptible in PBMC or EBV cellular lysates, and was inherited in a Mendelian fashion much like the DR $1_{x}$ phenotype, it is unlikely that the $50-\mathrm{kD}$ entity could be accounted for by artifacts of immunoprecipitation or techniques used in the 2-D gel analysis.

To incorporate these new findings we have expanded our nomenclature, designating those cells expressing the $50-\mathrm{kD}$ species as originating from individuals of the DR $1^{50}$ phenotype and those lacking the $50-\mathrm{kD}$ species as originating from the DR $1^{\text {null }}$ phenotype.

We were able to visualize the $50-\mathrm{kD}$ moiety on $2-\mathrm{D}$ gels using immunoprecipitations from both ${ }^{125}$ I-lactoperoxidase catalyzed surface-labeled (Fig. 1) and ${ }^{35} S$-methionine internally labeled lysates (data not shown). Lysates or solubilized immunoprecipitates processed with or without the reducing agent 2-mercaptoethanol failed to yield any change in the apparent molecular weight or IEF properties of the $50-\mathrm{kD}$ species (data not shown), leading us to conclude initially that the $50-\mathrm{kD}$ molecule represented a single polypeptide chain that was not disulfide bonded to DR $\alpha$ or $\beta$ chains.

Regulation of expression of the 50-kD protein. Using donor ReG who was known to carry the DR $1_{x}{ }^{50}$ phenotype, we enriched for resting $B$ and resting $T$ cells using two sequential rounds of SRBC rosetting. Unfractionated PBMC from the same donor were used to generate mitogen-activated B and T cell blasts. Anti-DR immunoprecipitations from ${ }^{125}$ I-labeled lysates of these populations demonstrated that activated $B$ and $T$ cells and resting $B$ cells all contained the $50-\mathrm{kD}$ protein with $\mathrm{DR} \alpha$ and $\beta$. Anti-DR mAbs failed to precipitate $\alpha$ and $\beta$ chains from resting $T$ cells, as expected, and did not contain the 50-kD species (Fig. 2). Also, IL-2-dependent TLC derived from individuals having the DR $1_{x}$ phenotype consistently expressed the $50-\mathrm{kD}$ protein, whereas lysates of $\mathrm{DR} 1^{-}$or $\mathrm{DR} 1_{\mathrm{n}}$ clones did not (data not shown). Similarly, gamma interferon-treated fibroblasts (graciously supplied by Dr. David Maurer from our laboratory) from individuals having the $\mathrm{DR} 1_{\mathrm{x}}$ phenotype expressed the $50-\mathrm{kD}$ complex whereas treated fibroblasts from DR $1_{n}$ individuals did not (data not shown). Therefore, we believe that the appearance of the $50-\mathrm{kD}$ protein on the surface of these cells is regulated in a fashion similar to other class II proteins, in particular DR.

Exclusive precipitation of the 50-kD protein using anti-DR $m A b s$. From a panel of anti-class II mAbs, only those with specificity for DR were able to co-precipitate the $50-\mathrm{kD}$ protein from lysates of $D R 1_{x}{ }^{50}$ cells (Fig. 3). Co-precipitation of the $50-\mathrm{kD}$ protein was noticeably absent from immunoprecip- 

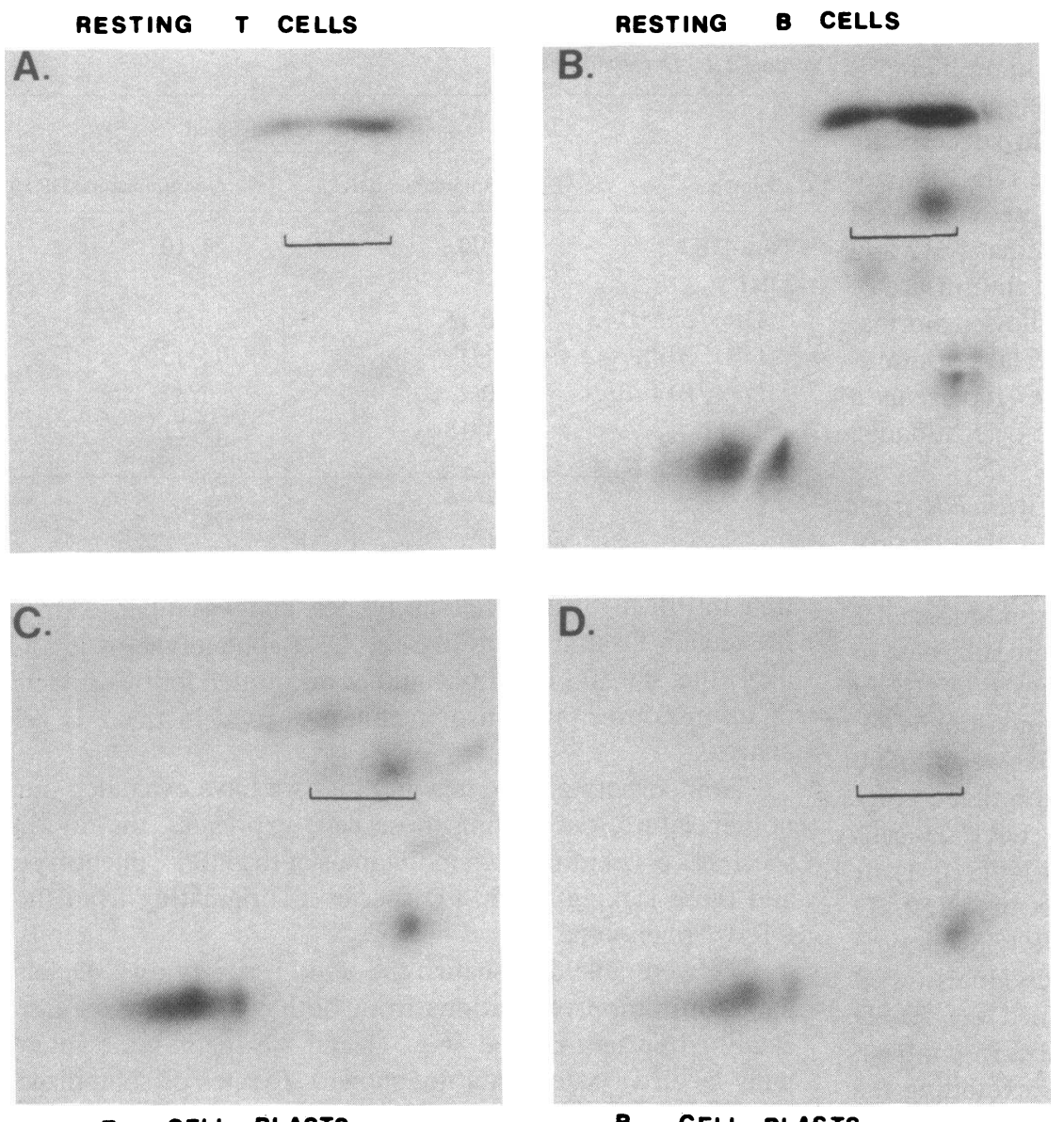

Figure 2. The $50 \mathrm{kD}$ species is regulated like class II molecules. Anti-DR immunoprecipitates (mAb L243) from B14;DR $1_{x}$ cis cellular lysates (ReG) were analyzed by 2-D PAGE. Resting $T$ or $B$ cells from peripheral blood were isolated by $S R B C$ rosetting. $T$ cell blasts were derived from day 4 Con A cultures; $B$ cell blasts were T CELL BLASTS from day 7 LPS-dextran sulfate cultures.
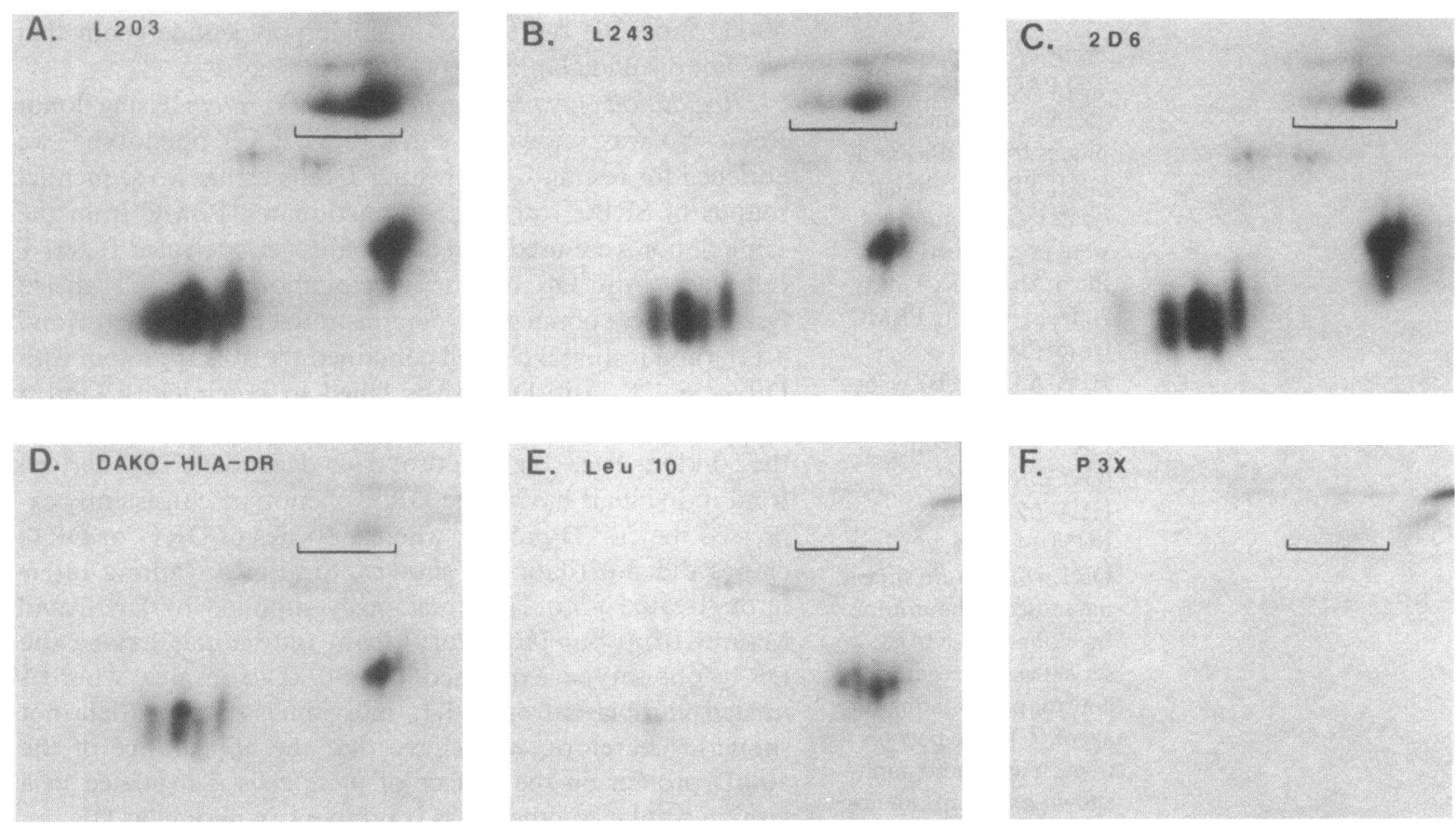

Figure 3. Exclusive precipitation of the 50-kD species with anti-DR mAbs. A B14;DR $1_{\mathrm{x}}$ cis EBV cellular lysate (GLG) was immunoprecipitated with mAb against DR (L203, L243, 2D6, and Dako-HLADR) or DQ (Leu 10) and the precipitates were analyzed by 2-D PAGE; culture supernatant from the murine myeloma P3X63Ag8
$(F)$ was utilized in negative control immunoprecipitations. Orientation of $\alpha$ and $\beta$ polypeptide chains is as given in Fig. 1. We believe that molecules appearing just below the bracketed 50-kD region represent co-precipitating class I heavy chains. 
itations utilizing anti-DQ (Leu 10; Fig. $4 E$ ) and anti-DP (B7/21; data not shown) mAbs. We interpret this to mean that the $50-\mathrm{kD}$ molecule shares crossreactive determinants only with DR $\alpha$ and/or $\beta$ chains or that the 50-kD species noncovalently complexes with DR molecules but not with $\mathrm{DQ}$ or DP molecules. In further experiments (not shown), we have found that the $50-\mathrm{kD}$ complex is not a class I antigen because it is not precipitated with $\mathrm{mAb}$ against HLA-A, B, C or $\beta-2$ microglobulin, nor does it represent a chondroitin sulfate modified invariant chain.

The 50-kD species includes $D R$ antigenic determinants. To pursue this evidence for common antigenic determinants between the $50-\mathrm{kD}$ protein and DR $\alpha$ and/or $\beta$ chains, we ran unlabeled anti-DR immunoprecipitations on 2-D gels, transferred them to nitrocellulose paper, and immunoblotted with a panel of class II mAbs. All anti-DR mAbs tested had specificity for the 50-kD molecule (L243, Fig. 4 B), whereas anti-DQ mAbs did not blot (data not shown).

Dissociation of the 50-kD species by boiling. After excising spots representative of DR $\alpha$ and $\beta$ and the $50-\mathrm{kD}$ species from 2-D gels followed by elution and rerunning on one-dimensional SDS-PAGE gels under nonreducing conditions, we observed that the 50-kD band dissociated into two constituent chains if the eluted material was boiled before rerunning. If treatment did not include boiling, no separation was apparent (Fig. 5, compare lanes 3 and 6). The component chains of the 50-kD complex appeared to have molecular weights equivalent to DR $\alpha$ and $\beta$ chains (Fig. 5, compare lanes 6 and 7).

Enzymatic susceptibility and peptide mapping. Successful enzymatic digestion of the 50-kD complex could not be achieved unless boiling preceded digestion. When eluted material representative of the 50-kD moiety was subjected to digestion by Staphylococcus aureus V8 protease, chymotrypsin, or papain without prior boiling, no peptide fragments were dis-
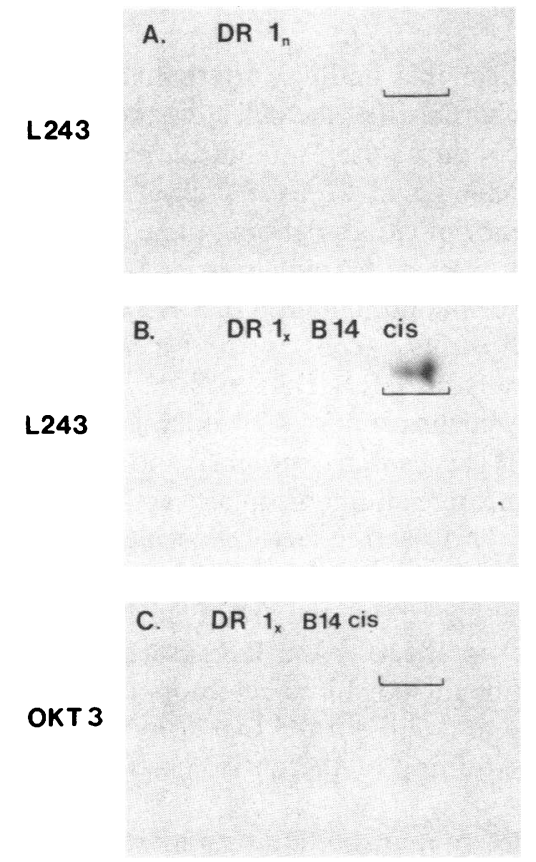

Figure 4. The 50-kD species includes DR antigenic determinants. Anti-DR immunoprecipitates from EBV cellular lysates of DR $1_{n}$ (JiN, $A$ : HLA-A2,11; B44,27; Cw2,5; DR 1,4) (DoH, $B$ and $C$ : HLAAw33/2; B14/w62; C-/w3; DR 1/4) individuals were separated by 2-D PAGE and subjected to analysis via Western blotting with L243 or OKT3 mAb followed by ${ }^{125}$ I-sheep anti-mouse Ig. Failure of individual DR $\alpha$ or $\beta$ chains to be recognized by these reagents is interpreted to mean that the corresponding determinants were lost after dissociation of the two peptides or after denaturation in SDS. and $\mathrm{B} 14 ; \mathrm{DR} 1_{\mathrm{x}}$ cis

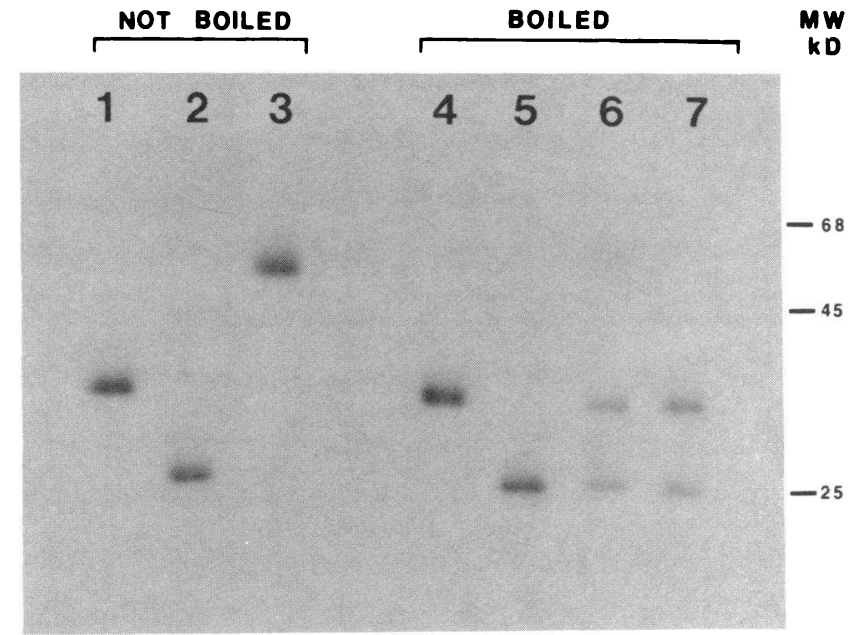

Figure 5. The 50-kD species dissociates after boiling. Material representative of DR $\alpha$ and $\beta$ or the $50-\mathrm{kD}$ species from a B14;DR $1_{\mathrm{x}}$ cis EBV-transformed cell line (TaT) was eluted from 2-D PAGE gels, boiled or not boiled, and analyzed on a $10 \%$ acrylamide one-dimensional SDS gel under nonreducing conditions. Lanes 1 and 4, DR $\alpha$. Lanes 2 and 5, DR $\beta$. Lanes 3 and 6, 50-kD species. Lane 7, DR $\alpha$ and $\beta$ mixed.

cernible (Fig. $6 \mathrm{~A}$, compare lanes 3 and 6 ). However, boiling followed by enzymatic digestion produced a peptide map virtually identical to that of purified DR $\alpha$ and $\beta$ chains mixed together (Fig. $6 \mathrm{~B}$, compare lanes 6 and 7). These data suggest that the $50-\mathrm{kD}$ species is composed of DR $\alpha$ and $\beta$ chains, but the inherent associative properties or the configurations of these two chains are sufficiently different from conventional DR $\alpha$ and $\beta$ chains as to preclude separation under conditions that include SDS and $8 \mathrm{M}$ urea or reducing agents such as $5 \%$ 2-mercaptoethanol.

\section{Discussion}

We have observed that $\mathrm{DR} 1^{+}$cells of some individuals failed to mediate activation and proliferation of $T$ lymphocyte clones either restricted to or specific for DR1. An unusually high association (87.0\%) of this phenomenon with haplotype inheritance of HLA-B14 and/or nonclassical 21-OH deficiency coupled with previous mapping of both the HLA-B14 and 21-OH genes telomeric to the DR subregion have allowed us to use these secondary features as tentative markers for defective antigen presentation of DR1. However, the identification of $\mathrm{DR} 1_{\mathrm{x}}$ cells from our panel that were $\mathrm{B} 14^{-} ; \mathrm{DR} 1^{+} 21-\mathrm{OH}$ normal or of $\mathrm{DR} 1_{\mathrm{n}}$ cells that were $\mathrm{B} 14^{+} ; \mathrm{DR} 1^{+}$cis $21-\mathrm{OH}$ deficient would suggest that the association is not absolute, and that although all three phenotypic traits are tightly linked, they can be separated by recombination. Because defective antigen presentation was always seen in conjunction with $D R 1_{x}$, we believe that the gene(s) causing abnormal antigen presentation is linked closer to or is identical to some gene(s) of the DR subregion.

Inheritance of the DR $1_{x}$ phenotype within the families we studied appeared to follow normal Mendelian patterns of segregation. In two instances, we had access to cells from unrelated "natural hybrid" individuals inheriting one parental DR1 haplotype encoding the competent stimulator (DR $1_{n}$ ) phenotype and another, encoding the incompetent stimulator 

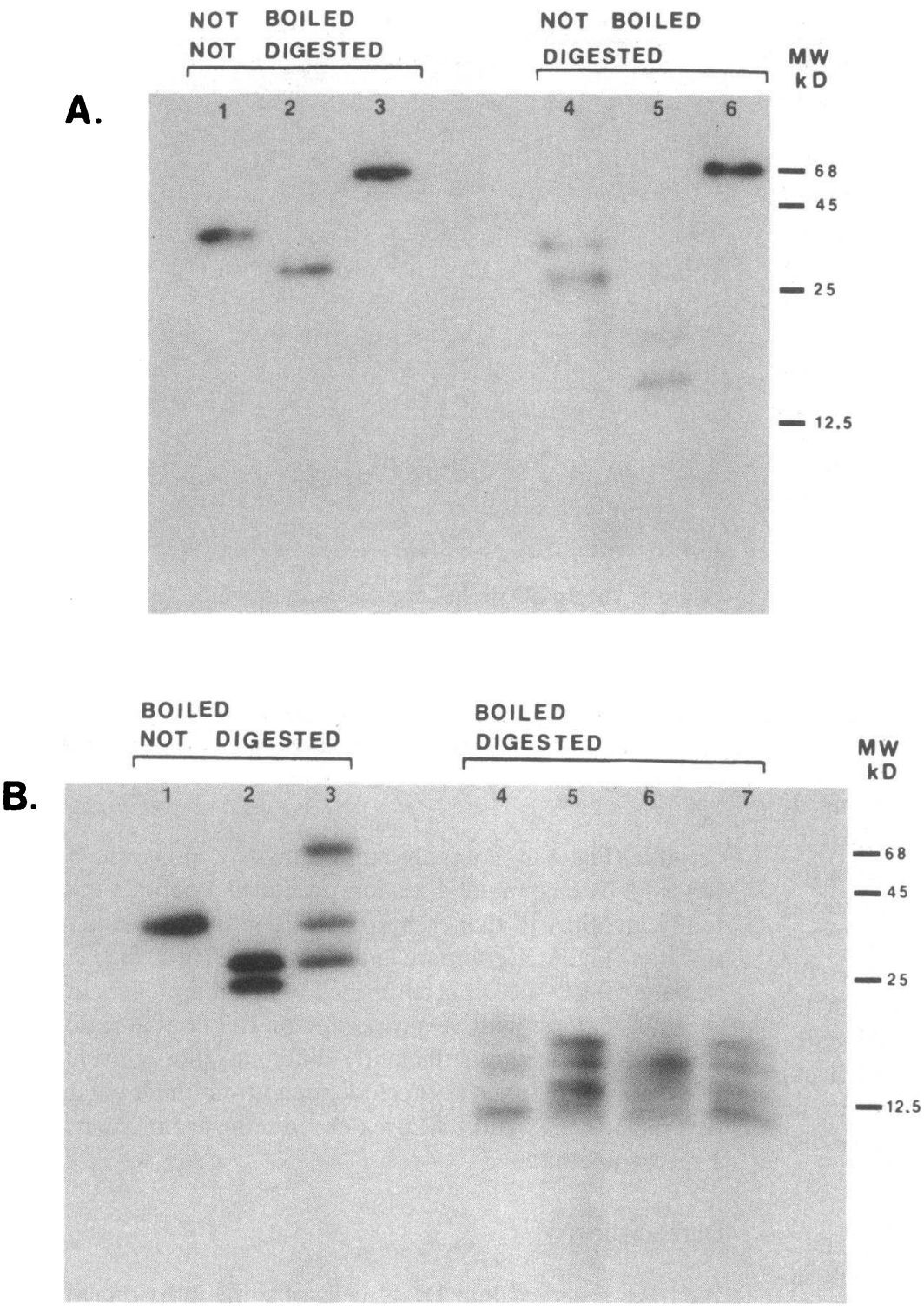

Figure 6. Enzymatic susceptibility and peptide mapping of the $50-\mathrm{kD}$ species. DR $\alpha$ and $\beta$ chains or the $50-\mathrm{kD}$ species from a B14;DR $1_{\mathrm{x}}, 1_{\mathrm{x}}$ cis $(\mathrm{DiO}$, $A$ ) or B14;DR $1_{\mathrm{x}}, 3$ cis (ALG, B) EBV-transformed cell line were digested with Staphylococcus aureus V8 protease with $(B)$ or without $(A)$ previously boiling the eluted material. Lanes 1 and 4 (both $A$ and $B$ ), DR $\alpha$. Lanes 2 and 5 , DR $\beta$. Lanes 3 and 6 , 50-kD species. Lane 7 ( $B$ only), DR $\alpha$ and $\beta$ mixed. We believe that the lower $M_{r}$ DR $\beta$ band apparent in immunoprecipitates of some cellular lysates (lane $2, B$ ) corresponds to the DR $\beta_{2}$ protein product.
$\left(D R 1_{x}\right)$ phenotype. Overall, cells of these "hybrid" $D R 1_{x}, D R 1_{n}$ individuals expressed the nonstimulatory $\left(D R 1_{x}\right)$ phenotype. Repeat testing of the stimulatory capacity of each family member's cells again confirmed these results. Although some caution must be exercised in drawing conclusions from this limited sample, it appears that the $D R 1_{x}$ phenotypic trait is dominant and may contain a trans-acting factor affecting expression of both DR1-bearing haplotypes. These particular examples also support our contention that defective antigen presentation is not representative of an as yet unidentified serological "split" of DR1. Testing cells from additional natural hybrid individuals is required to substantiate these conclusions and will be carried out as cells from such rare pedigrees become available. We also intend to construct in vitro somatic cell hybrids from cell lines that combine both phenotypes.

It is especially notable that defective antigen presentation of DR1 is limited to the representative $D R 1_{n}$-specific and -restricted clones reported here. $\mathrm{DR} 1_{\mathrm{x}}, 2$ and $\mathrm{DR} 1_{\mathrm{x}}, 7$ stimulator cells were able to mediate normal proliferative responses from DR2 and DR7 alloreactive clones, respectively. We plan to utilize additional alloreactive clones specific for these and other DR alleles to confirm this finding. Alternatively, the possibility remains that inheritance of the defective trait(s) on the $\mathrm{DR} 1_{\mathrm{x}}$ haplotype may conduct a trans modification of other epitopes or other DR products that we have not yet investigated although the frequency of clones defining these missing or modified determinants may be extremely low. Again, in light of the evidence for normal presentation of DR2 or DR7 from opposing haplotypes of $D R 1_{x}$ cells, we find it puzzling that phenotypically heterozygous $\mathrm{DR} 1_{\mathrm{x}}, \mathrm{DR} 1_{\mathrm{n}}$ cells cannot adequately present the $D R l_{n}$ allelic product. Cell-mixing experiments where $D R 1_{x}$ and $D R 1_{n}$ cells were combined and used as stimulators failed to demonstrate an intercellularly acting suppressive agent. Hence, if a trans-acting factor associated with the $\mathrm{B} 14 ; \mathrm{DR} 1_{x}$ haplotype exists, it must be operative intracellularly. Our collective data suggest that the modifying agent(s) responsible for the defect is affecting the DR1 allele only. Other DR alleles may not be included in a determinant-altering process or may be able to retain normal function by compensating during tertiary folding of the entire class II DR complex.

Not all polymorphic determinants of DR1 itself are modi- 
fied or masked in this alteration process since we have generated one $\mathrm{T}$ lymphocyte clone capable of responding to all $D R 1^{+}$stimulator cells regardless of defined $D R 1_{x}$ or $D R 1_{n}$ phenotypes. Serological typings of these cells also tend to support this observation because no serological differences were detected using a large battery of DR1-specific alloantisera that presumably recognize polymorphic epitopes within the $\beta 1$ domain of the DR1 antigenic complex.

We have not yet determined a molecular cause for the aberrant structural assembly of the $D R 1^{50}$ complex. Since the constitutive chains of the $50-\mathrm{kD}$ complex are very similar if not identical in size to corresponding conventional DR chains, no major deletions or insertions in the protein sequence are predicted. Differential expression of a secondary, linked gene responsible for posttranslational modifications of the $D R 1_{x}$ vs. the $D R 1_{n}$ complex could account for the appearance of the $50-\mathrm{kD}$ heterodimer and consequently the eradication of one or more antigenic determinants. Alternatively, a mutation in one or more DR subregion genes could generate the same result. In either instance, increased avidity of interaction between the two chains could interfere with antigen-presenting properties or with potential binding interactions of the class II complex and a specific $T$ cell receptor complex.

In summary, we have evidence for a novel combinatorial association between constituent chains of the DRI complex, the product of which may functionally interfere with or compete for normal $T$ cell receptor recognition of $D R 1$ as both an alloantigen and as a restricting element. It is especially noteworthy that a defect of this nature is highly correlated with the B14;DR1-extended haplotype commonly inherited with nonclassical 21-OH deficiency, a haplotype known to contain at least one major rearrangement of DNA downstream of the DR subregion. Others have speculated that an extended haplotype of this nature may be retained if duplications of the C4B and 21-OHB genes carried with B14 and DR1 introduce sufficient misalignments of the chromosomes to suppress recombination in that region and across portions of the adjoining MHC (35). Although deficiencies of immunological function in such patients have not previously been reported, our data suggest that additional HLA gene product structural abnormalities are inherited with this haplotype, that modifications of the DNA extend beyond the class III region, and that at least one consequence may be abnormal surface presentation of the DR1 antigen.

\section{Acknowledgments}

We are indebted to Cindy Callaway for the serological HLA typings, Dr. David Maurer for the DP cellular typing, Dr. Bruce Keenan and Krystal Davis for the ACTH testing, and Sue Floyd for her skillful secretarial assistance.

This work was supported in part by U. S. Public Health Service grants AI15394, AI17897, AI21289, CA40552, and RR-001888.

\section{References}

1. Kaufman, J. F., C. Auffray, A. J. Korman, D. A. Shackelford, and J. Strominger. 1984. The class II molecules of the human and murine major histocompatibility complex. Cell. 36:1-13.

2. Hanke, J. H., R. G. Cook, J. W. Leone, M. Van, and R. R. Rich. 1986. Molecular characterization of a subtype of $D Q w l$ recognized by hapten-specific T cells. Immunogenetics. 24:209-216.

3. Kornbluth, J., and B. Dupont. 1980. Cloning and functional characterization of primary alloreactive human T lymphocytes. $J$. Exp. Med. 152:164s-181s.

4. Zeevi, A., C. Scheffel, K. Annen, G. Bass, M. Marrari, and R. J. Duquesnoy. 1982. Association of PLT specificity of alloreactive lymphocyte clones with HLA-DR, MB and MT determinants. Immunogenetics. 16:209-218.

5. Spits, H., J. Borst, M. Giphart, J. Coligan, C. Terhorst, and J. E. DeVries. 1984. HLA-DC antigens can serve as recognition elements for human cytotoxic T lymphocytes. Eur. J. Immunol. 14:299-304.

6. New, M. I. 1985. Clinical and endocrinological aspects of 21-hydroxylase deficiency. In Congenital Adrenal Hyperplasia. M. I. New, editor. New York Academy of Sciences, New York. 1-27.

7. Dupont, B., R. Virdis, A. J. Lerner, C. Nelson, M. S. Pollack, and M. I. New. 1985. Distinct HLA-B antigen associations for the saltwasting and simple virilizing forms of congenital adrenal hyperplasia due to 21-hydroxylase deficiency. In Histocompatibility Testing 1984. E. D. Albert, M. P. Baur, and W. R. Mayr, editors. Springer-Verlag New York Inc., New York. 660-661.

8. Scholz, S., W. Höller, D. Knorr, F. Bidlingmaier, H. Zander, and E. D. Albert. 1984. Three different HLA associations in the three types of 21-hydroxylase congenital adrenal hyperplasia. In Histocompatibility Testing 1984. E. D. Albert, M. P. Baur, and W. R. Mayr, editors. Springer-Verlag New York Inc., New York. 658-659.

9. White, P. C., D. Grossberger, B. J. Onufer, D. D. Chaplin, M. I. New, B. Dupont, and J. L. Strominger. 1985. Two genes encoding steroid 21-hydroxylase are located near the genes encoding the fourth component of complement in man. Proc. Natl. Acad. Sci. USA. 82:1089-1093.

10. Carroll, M. C., R. D. Campbell, and R. R. Porter. 1985. Mapping of steroid 21-hydroxylase genes adjacent to complement component $\mathrm{C} 4$ genes in HLA, the major histocompatibility complex in man. Proc. Natl. Acad. Sci. USA. 82:521-525.

11. White, P. C., J. Werkmeister, M. I. New, and B. Dupont. 1986. Steroid 21-hydroxylase deficiency and the major histocompatibility complex. Hum. Immunol. 15:404-415.

12. Raum, D., Z. Awdeh, J. Anderson, L. Strong, J. Granados, L. Teran, E. Giblett, E. J. Yunis, and C. A. Alper. 1984. Human C4 haplotypes with duplicated C4A or C4B. Am. J. Hum. Genet. 36:7279.

13. Brown, M. F., M. Van, S. L. Abramson, E. J. Fox, and R. R. Rich. 1984. Cellular requirements for induction of human primary proliferative responses to trinitrophenyl-modified cells. J. Immunol. 132:19-24.

14. Seldin, M. F., and R. R. Rich. 1978. Human immune responses to hapten-conjugated cells. Primary and secondary proliferative responses in vitro. J. Exp. Med. 147:1671-1683.

15. Wu, Y., I. Ernberg, M. G. Masucci, D. Johnson, E. Klein, and G. Klein. 1982. Human T cell growth factor (TCGF) produced by repeated stimulation of non-adherent human lymphocytes. J. Immunol. Methods. 51:35-44.

16. Hercend, T., E. L. Reinherz, S. Meuer, S. F. Schlossman, and J. Ritz. 1983. Phenotypic and functional heterogeneity of human cloned natural killer cell lines. Nature (Lond.). 301:158-160.

17. Watson, J. 1979. Continuous proliferation of murine antigenspecific helper T lymphocytes in culture. J. Exp. Med. 150:1510-1519.

18. Böyum, A. 1968. Isolation of mononuclear cells and granulocytes from human blood. Scand. J. Clin. Lab. Invest. 21 (Suppl. 97):77-89.

19. Chen, T. R. 1977. In situ detection of mycoplasma contamination in cell cultures by fluorescent Hoechst 33258 stain. Exp. Cell Res. 104:255-262.

20. Terasaki, P. I., and J. D. McClelland. 1964. Microdroplet assay of human serum cytotoxins. Nature (Lond.). 206:998-1000.

21. Bodmer, J. G., P. Pickbourne, and S. Richards. 1977. Ia Serology. In Histocompatibility Testing 1977. W. F. Bodmer, J. R. Batchelor, J. G. Bodmer, H. Festenstein, and P. J. Morris, editors. Munksgaard, Copenhagen. 35-84.

22. Maurer, D. H., W. E. Collins, J. H. Hanke, M. Van, R. R. Rich, 
and M. S. Pollack. 1985. Class II positive human dermal fibroblasts restimulate cloned allospecific $\mathrm{T}$ cells but fail to stimulate primary allogeneic lymphoproliferation. Hum. Immunol. 14:245-258.

23. Gutai, J. P., W. J. Meyer, A. Kowarski, and C. J. Migeon. 1975. Circadian variation of 17-hydroxyprogesterone (17-OHP), progesterone (P) and cortisol (F) in the plasma of normal adult male subjects. Chronobiologia. 2(Suppl. 1):26-38.

24. Weiner, M. S., C. Bianco, and V. Nussenzweig. 1973. Enhanced binding of neuraminidase-treated sheep erythrocytes to human T lymphocytes. Blood. 42:939-946.

25. Jones, P. P. 1980. Analysis of radiolabeled lymphocyte proteins by one- and two-dimensional polyacrylamide gel electrophoresis. In Selected Methods in Cellular Immunology. B. Mishell and S. M. Shiigi, editors. Freeman Publications, San Francisco. 398-440.

26. Lampson, L. A., and R. Levy. 1980. Two populations of Ia-like molecules on a human B cell line. J. Immunol. 125:293-299.

27. Hanke, J. H., M. F. Brown, M. S. Pollack, and R. R. Rich. 1985. Class II determinants recognized by TNP-specific cloned human T cell lines. Hum. Immunol. 14:59-76.

28. Brodsky, F., P. Parham, and W. Bodmer. 1980. Monoclonal antibodies to HLA-DRw determinants. Tissue Antigens. 16:30-48.

29. Chen, Y. X., R. L. Evans, M. S. Pollack, L. L. Lanier, J. H. Phillips, C. Rousso, N. L. Warner, and F. M. Brodsky. 1984. Charac- terization and expression of the HLA-DC antigens defined by anti-Leu 10. Hum. Immunol. 10:221-235.

30. Watson, A. J., R. DeMars, I. S. Trowbridge, and F. H. Bach. 1983. Detection of a novel human class II HLA antigen. Nature (Lond.). 304:358-361.

31. Brodsky, F. M. 1984. Biochemical characterization of cell surface antigens with monoclonal antibodies. In Lymphocyte Surface Antigens 1984. E. R. Heise, editor. American Society for Histocompatibility and Immunogenetics, New York. 100-102.

32. Cleveland, D. W., S. G. Fischer, M. W. Kirschner, and U. K. Laemmli. 1977. Peptide mapping by limited proteolysis in sodium dodecyl sulfate and analysis by gel electrophoresis. J. Biol. Chem. 252:1102-1106.

33. Pollack, M. S., B. Keenan, F. T. Christiansen, T. J. Cobain, R. L. Dawkins, and G. Clayton. 1986. The immunological detection of a 21-OH deficiency mutation HLA supratype. Am. J. Hum. Genet. 38:688-698.

34. Uchiyama, T., S. Broder, and T. A. Waldmann. 1981. A monoclonal antibody (anti-Tac) reactive with activated and functionally mature human T cells. I. Production of anti-Tac monoclonal antibody and distribution of Tac(+) cells. J. Immunol. 126:1393-1397.

35. White, P. C., M. I. New, and B. Dupont. 1985. Adrenal 21-hydroxylase cytochrome $\mathrm{P}-450$ genes within the MHC class II region. Immunol. Rev. 87:123-150. 